\title{
The Occupational Health and Safety Effect on Road Construction Worker Performance
}

\author{
Fourry Handoko ${ }^{1, *}$, Maranatha Wijayaningtyas ${ }^{2}$, Imam H. A. Kusuma ${ }^{2}$, Sutanto Hidayat ${ }^{2}$, A. Ismail ${ }^{3}$, \\ Z. Abdullah ${ }^{4}$ \\ ${ }^{1}$ Industrial Engineering, National Institute of Technology Malang, Indonesia \\ ${ }^{2}$ Civil Engineering, National Institute of Technology Malang, Indonesia \\ ${ }^{3}$ Department of Real Estate, Faculty of Build Environment, Universiti Teknologi Malaysia, Malaysia \\ ${ }^{4}$ Faculty of Engineering, Universiti Teknikal Malaysia Melaka, Malaysia
}

Received June 17, 2020; Revised August 1, 2020; Accepted August 25, 2020

\section{Cite This Paper in the following Citation Styles}

(a): [1] Fourry Handoko, Maranatha Wijayaningtyas, Imam H. A. Kusuma, Sutanto Hidayat, A. Ismail, Z. Abdullah, "The Occupational Health and Safety Effect on Road Construction Worker Performance," Civil Engineering and Architecture, Vol. 8, No. 5, pp. 750 - 759, 2020. DOI: 10.13189/cea.2020.080502.

(b): Fourry Handoko, Maranatha Wijayaningtyas, Imam H. A. Kusuma, Sutanto Hidayat, A. Ismail, Z. Abdullah (2020). The Occupational Health and Safety Effect on Road Construction Worker Performance. Civil Engineering and Architecture, 8(5), 750 - 759. DOI: 10.13189/cea.2020.080502.

Copyright $\mathrm{C} 2020$ by authors, all rights reserved. Authors agree that this article remains permanently open access under the terms of the Creative Commons Attribution License 4.0 International License

\begin{abstract}
This study was designed to analyze the factors of Occupational Health and Safety (OHS) implementation affecting the performance of road construction workers. The research employed a quantitative survey method by self-distributing questionnaires using simple random sampling to 50 road construction workers on a road-widening project, with a $99 \%$ response rate. The analysis based on the results of the questionnaire data through the validity test, reliability, and the multiple regressions testing: f-test and t-test of each statement item. Regarding the descriptive analysis test results, the most dominant among several elements of Work Safety variable statement was the appropriate use of work equipment, which was $81 \%$. In contrast, the practical result of the Occupational Health variable was the first aid kits provided by companies, which was $82 \%$. For the Worker Performance variable, the dominant result was the workers' attitude to conform to the rules leading to achieving work targets, which was $88 \%$. Furthermore, according to the results of multiple regressions testing, it can be concluded that the implementation of occupational safety and health had a positive effect on employee performance. The findings show that the application of OHS in construction projects affects the performance of workers which ultimately also determines the achievement of the company's work targets.
\end{abstract}

Keywords First Aid Kits, Personal Protective Equipment (PPE), Road Projects, Worker Attitudes, Work Targets

\section{Introduction}

The technology transfer program objectives are to enhance the capacity of human resource development, especially in technology $[1,2]$. Besides, technology transfer is recognized as a means to advance technology capability and is inseparable from the implementation of infrastructure and property construction $[3.4,5,6]$. The construction sector has become one of the crucial areas of the national economy in developed and developing countries $[7,8,9]$. Human resources have an essential role in the success and need special attention from the company $[10,11]$. The fact that humans are a significant asset in an organization or company must receive serious consideration, and they must be managed as best as they can. Concerning human resources, the management must manage resources systematically, efficiently, and with careful planning [12].

Worker performance defines the quality and quantity of work achieved by employees in performing their duties in 
conformity with the responsibilities given to them [10]. Additionally, in the performance of human resources, the occupational health and safety system must be of concern. In Indonesia, the number of work accidents is alarming. According to research conducted by the International Labor Organization (ILO), Indonesia ranks 52 out of 53 countries with poor OHS management, even though the costs incurred by the company will be substantial should there be an accident at work [13].

According to data from the International Labor Organization (ILO) in 2010, there were more than 2 million people died due to accidents and occupational diseases each year. Approximately 160 million people suffer from occupational diseases and 270 million cases of work accidents annually throughout the world [14]. Those data indicate that occupational health and safety in Indonesia is low as they have not received attention and become a part of the culture in Indonesian society [15].

As stated by the construction management agency staff of the Ministry of Public Works in the construction management sector, the implementation of Occupational Health and Safety (OHS) programs in each development project is not good. The Ministry of Public Works has also required every contractor to carry out OHS. A variety of OHS programs implemented in the construction project of the shaft road and entry monument of the integrated district government office in Sumenep City District, Sumenep Regency, include providing adequate Personal Protective Equipment, health facilities, and social security for workers. Thus, this study focused on the construction of the shaft and monument construction into the district government office.

This study will study the case in the construction mentioned above project only in Sumenep City District, Sumenep Regency, Indonesia, this study is only specific to one development site and will not be widen to other aspects. In this case, the researchers sought to confirm the implementation of $\mathrm{OHS}$ in the project. From the description, the identification of the problems are:

1. Lack of sensitivity from the company regarding the importance of workers occupational health and safety (OHS) on a project under the company auspices.

2. Lack of attention from the company to provide better services and equipment related to work safety for its workforce as an essential factor of all project objectives.

3. Lack of understanding by workers of the risks regarding occupational health and safety (OHS).

However, there is a gap from previous research on the effect of the implementation of OHS by construction workers on performance improvement. According to Busyairi [16], it showed that the variables of work safety (work environment, work safety equipment, work methods) and occupational health variables (health checks, rest hours, ergonomics) had positive and significant contributions on worker productivity in manufacturing companies.
Nonetheless, the results of Firmanzah's research [17] in the state electricity company showed that work safety variables had a negative and significant effect on employee performance. Therefore, the inequality of the results provides an opportunity to examine the extent of the influence of OHS on the performance of workers in cases in construction projects, especially on road construction projects.

Accordingly, the problem formulation is as follow:

1. What are the factors of implementing Occupational Health and Safety (OHS) that can affect the performance of workers on the construction project of the shaft road and entry monument of the integrated district government office in Sumenep City District, Sumenep Regency?

2. How is the performance of workers affected by the implementation of Occupational Health and Safety (OHS) on the construction project of the shaft road and entry monument of the integrated district government office in Sumenep City District, Sumenep Regency?

This study can enrich the researchers' knowledge about the effect of Occupational Health and Safety (OHS) programs implementation and work motivation on worker productivity. It can also be used as further research material for other researchers interested in this field and to learn how much the implementation of Occupational Health and Safety (OHS) programs and work motivation affect employee productivity. Thereby, companies can find out the extent of the program that has been applied and how important it is to carry out the Occupational Health and Safety (OHS) program on employee performance.

\section{Literature Review}

\subsection{Occupational Health and Safety (OHS)}

Many industries put OHS in a prioritised need. Without its application in the work environment, there will get a high chance of work accidents. According to occupational safety research by Firmanzah et al. [17], the critical factors of applying OHS are:

\section{Humanity}

Employees are people who should not be seen merely as a means of production; they are individuals serving as the company's assets. Thus, every human being needs to be protected from all possible threats and dangers.

\section{Government Regulations}

A company, regardless of the type of business, aims to create a product that can be used by the community; its existence is related to the community, and so it is regulated through various regulatory mechanisms. 


\section{Economy}

Economic factors are also the driving force for the implementation of OHS maintenance in a company. Understandably, a company's operations will always follow economy consideration, such as seeking profit. Maintaining OHS means the company has to pay more. However, the costs incurred will be even higher if a work accident occurs. OHS maintenance intends to prevent work accidents.

Swasto [18] asserted work safety involves the whole process of protecting workers against the possibility of hazards arising in the work environment. There are two attempts to provide work safety for employees, according to Soeprihatno [19], they are:

1. Preventive efforts such as controlling or inhibiting the source of danger in the workplace so that it can be reduced or not cause risk to employees.

2. Repressive efforts such as dealing with incidents or accidents caused by sources of danger in the workplace.

In addition to preventing employees from accidents, the company also needs to maintain employees' health which includes physical and mental health. Employees can be affected due to illness, stress, or accidents. According to Manulang [20] and Simamora [21], there are three indicators of Occupational Health:

1. Medical work environment

2. Workforce health environment

3. Maintenance of workforce health

\subsection{Occupational Health and Safety (OHS) and Worker Performance}

Simamora [21] says that performance refers to the degree of achievement of tasks, where it can form an employee's job. Performance reflects how well employees meet the requirements of a job. Mangkunegara [22] argues that human resource performance is a term derived from the word Job Performance or Actual Performance (work performance or actual achievement achieved by someone). Therefore, it concludes that the performance of human resources is work output (quality) both in quality and quantity made per unit period in carrying out their work following the responsibilities given to them.

Several studies in Indonesia show that there is an influence between OHS and the performance of workers in several different types of work such as workers in the manufacturing industry, electricity companies, and general services $[16,17,23,24,25]$. However, the results of the previous studies were different, some showing that health and safety had a positive effect, but others showed a negative influence between OHS and employee performance. Thus, this study using the same variables as some of the previous reviews will test the effect of OHS on the performance of workers in construction projects. The hypothesis formed is:

1. H1 - work safety positively influences worker performance

2. H2 - occupational health positively affects worker performance

The variables to be used are as shown in Table 1, with the research conceptual framework shown in Figure 1.

Table 1. Research Variables

\begin{tabular}{|c|c|c|c|}
\hline No. & & Variables and Indicators & Sources \\
\hline 1 & Work Safety & $\begin{array}{ll}- & \text { Guarantee of Occupational Safety and Health } \\
\text { - } & \text { Occupational Safety and Health Training } \\
\text { - } & \text { Physical work environment } \\
\text { - } & \text { Psychological, social environment } \\
\text { - } & \text { Work safety equipment } \\
\text { - } & \text { Types of work tools } \\
\text { - } & \text { Safety devices }\end{array}$ & $\begin{array}{l}{[14]} \\
{[15]} \\
{[21]} \\
{[22]} \\
{[23]}\end{array}$ \\
\hline 2 & $\begin{array}{c}\text { Occupational } \\
\text { Health }\end{array}$ & $\begin{array}{ll}\text { - } & \text { Personal Protective Equipment } \\
\text { - } & \text { Workload } \\
\text { - } & \text { Work environment and health insurance } \\
\text { - } & \text { Working conditions } \\
\text { - } & \text { Maintenance of workforce health } \\
\text { - } & \text { Medical examination } \\
\text { - } & \text { Rest time } \\
\text { - } & \text { Ergonomics } \\
\text { - } & \text { Morkplace cleanliness } \\
\text { - } & \text { Enough lighting when overtime } \\
\text { - } & \text { Sound noise } \\
\text { - } & \text { Air temperature }\end{array}$ & $\begin{array}{l}{[14]} \\
{[15]} \\
{[21]} \\
{[22]} \\
{[23]}\end{array}$ \\
\hline 3 & $\begin{array}{c}\text { Worker } \\
\text { Performance }\end{array}$ & $\begin{array}{ll}- & \text { Working Hours } \\
\text { - } & \text { Quantity and quality of work } \\
\text { - } & \text { Timeliness } \\
\text { - } & \text { Work equipment } \\
\text { - } & \text { Job opportunities } \\
\text { - } & \text { Knowledge } \\
\text { Skills }\end{array}$ & $\begin{array}{l}{[14]} \\
{[15]} \\
{[21]} \\
{[22]} \\
{[23]}\end{array}$ \\
\hline
\end{tabular}




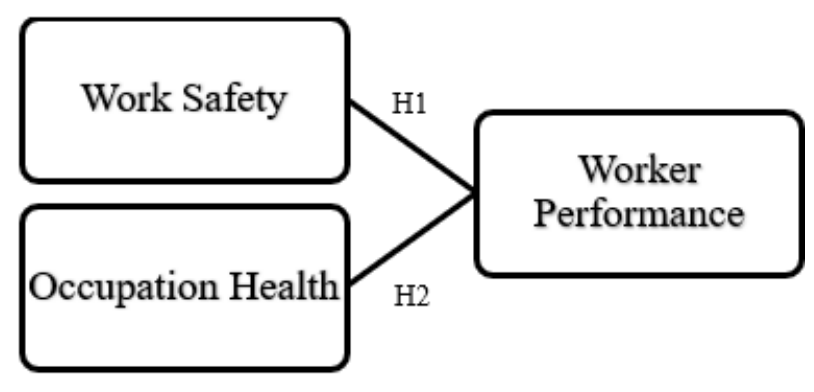

Figure 1. Research conceptual framework

\section{Materials and Methods}

This section discusses the research methods used to analyse the Occupational Health and Safety (OHS) implementation factors affecting the performance of workers on the construction project of the shaft road and entry monument of the integrated district government office in Sumenep City District, Sumenep Regency. The research strategy determines to obtain the data needed in advance. The following aspects affecting the types of procedures are used in this study:

a. The type of statement used

b. Control of the events understudy

c. Focus on current events

\subsection{Research Methods}

The method used in this research was descriptive research, and the type was quantitative research. According to Sugiyono [26], descriptive study is the research conducted to determine the value of independent variables, either one or more variables (independent) without making comparisons or connecting with other variables. Moreover, it is a quantitative research; according to Sugiyono [26], it is the research conducted by obtaining data in the form of numbers or compiled qualitative data.

\subsection{Research Design}

Research design is a framework or plan for conducting studies that will be used as a guide in collecting and analysing data. Based on the problem formulation and research objectives, it can be concluded that the design used in this study uses descriptive and verification analysis methods. According to Sugiyono [26] that the descriptive analysis method is a statistic used to analyse data in a way, describe the data that have been collected as they are. While verification applied to test hypotheses using statistical test equipment, this study uses multiple linear regression analysis test equipment.

\subsection{Data Collection Technique}

According to Sugiyono [26], data collection techniques are the most strategic step in research because the primary purpose of the research is to collect data. In this study, researchers used two types of data: primary and secondary; the primary data were used to find out the effect of the implementation of Occupational Health and Safety (OHS) on employee performance and the secondary data were to support research data presentation. The data collection processes were as follow:

\section{Primary Data}

Primary data are a source of data obtained directly from the source (not through intermediary media). It can be in the form of individual or group subject opinions, observations of objects (physical), events or activities, and test results. The method used to obtain primary data is the survey method:

- The survey method is a central data collection method using a written statement.

- This method requires a contact or relationship between the researcher and the subject (respondent) of the study to obtain the necessary data.

- The data obtained are mostly descriptive, but data collection design is to solve cause and effect or express ideas.

- They are generally used to collect the same data from many subjects.

- The techniques used are distributing questionnaires and conducting interviews.

2. Secondary Data

Secondary data are a source of research data obtained indirectly through intermediary media (collected and recorded by other parties). Secondary data are generally in the form of evidence, notes or historical reports that have been arranged in archives (documentary data) that are published and not published.

\subsection{Population and Sample}

The population is a generalisation area consisting of objects or subjects with specific qualities and characteristics determined by researchers to study and draw a conclusion [11]. The population in this study was all 50 workers on the construction project of the shaft road and entry monument of the integrated district government office in Sumenep City District, Sumenep Regency.

The sampling method, according to Sugiyono [26], is to determine the sample to be used in research. The non-probability sampling employ in this study, which was saturated sampling. Then, the saturated sampling technique is when all members of the population are used as samples. This method is applied if the population is relatively small or less than 30 people. A saturated sample is also called a census, in which all members of the population as respondents. The researchers use this type of sampling since there were 50 people in the population. 
The researchers used a percentage error of $1 \%=0.01$ for a small population, then calculated the sample size using the Slovin technique; according to Sugiyono [26], it is as follows :

$$
n=\frac{N}{1+N e^{2}} \ldots \ldots \ldots
$$

In which:

$\mathrm{n}=$ sample size

$\mathrm{N}=$ population size i.e. project workers

$\mathrm{e}=$ per cent leeway for inaccuracy due to error taking.

Then the number of samples to be examined is:

$$
\mathrm{n}=\frac{50}{1+50(0.01)^{2}}
$$

$\mathrm{n}=49.9=50$ people

\subsection{Data Analysis Technique}

In this study, the researchers used a descriptive and associative analysis approach to determine the causal relationship with the survey approach considering the variables to be processed and the purpose to present a structured, factual, and accurate illustration of the facts and the relationships between the variables studied.

The data analysis is an activity carried out after the data from all respondents were collected [26]. It involves grouping data based on variables and types of respondents, stimulating data based on variables from all respondents, presenting data from each variable studied, doing calculations to answer the problem formulation, and doing calculations to test proposed hypotheses.

The instruments used in the research are then tested for validity and reliability. A validity test confirms whether the instrument used to obtain data in the study can be used or not, while the reliability test confirms whether the instrument will produce the same data in several times testing or to measure the same object. The validity test of the instrument in this study was conducted to find out whether the measuring instrument, which was a questionnaire, could carry out its functions. As explained in the research method, a statistical approach was used through the correlation coefficient of the item's statement score with the total item's statement score; if the correlation coefficient is greater or equal to 0.30 , the statement is declared valid.

A reliability test applied to find out whether the measuring instrument designed in the form of a questionnaire can rely upon; a measuring instrument is reliable if it will give relatively the same results (not much different) when used repeatedly. A statistical approach is used to see whether a measure is reliable or not; it is done through the reliability coefficient. If the reliability coefficient is greater than 0.60 , the whole statement is declared to be reliable.

After the data collected from the field, then a descriptive analysis is performed by displaying the percentage of the average value of each indicator. This method is used to describe the implementation of occupational health and safety at the company and the level of performance of workers after the implementation of the Occupational Health and Safety (OHS) system.

The quantitative approach used in this research was the multiple linear regression analyses to test the hypotheses. Multiple linear regression analysis is applied if there are several independent variables of at least two or more. The multiple linear regression analysis aims to examine the effect of the independent variables on the dependent variables, either partially or collectively. It is also useful to find out which independent variable most influences the dependent variable by using or calculating multiple linear regression equations.

\section{F-test}

F-Test Analysis is used to find out the positive, negative, and significant relationship between the variables 1-variable Occupational Safety (X1) and Occupational Health (X2) simultaneously with the variable of Worker Performance $(\mathrm{Y})$.

\section{T-test}

T-Test analysis is used to test the regression coefficient partially and determine whether the effect of the variables Safety (X1) and Occupational Health (X2) on the variable Worker Performance (Y) is significant or not.

\section{Linear Regression Equations}

According to Sugiyono [26], multiple linear regression analysis is intended to predict the condition (the ups and downs) of the dependent variable (criterion). However, if two or more independent variables as a predictor factor are manipulated (raised the value down); so, multiple regression analysis will be conducted if the number of independent variables is at least two.

\subsection{Research Instruments}

In this study, researchers used the Likert scale 5 to measure the level of performance of workers; some examples of the Likert scale in this study are presented in Table 2.

Table 2. Likert scale

\begin{tabular}{|c|c|}
\hline Likert Scale & Score \\
\hline Strongly Disagree (SD) & 1 \\
\hline Disagree (D) & 2 \\
\hline Neutral (N) & 3 \\
\hline Agree (A) & 4 \\
\hline Strongly Agree (SA) & 5 \\
\hline
\end{tabular}

According to Sugiyono [26], the notion of a research variable is an attribute, trait, or value of people, objects or activities having individual variations determined by researchers to be studied and conclusions could be drawn. In this study, there are three variables and indicators, as shown in Table 3:

- Work Safety required in a job to guarantee the welfare of working life (X1) 
- Occupational Health means a prosperous condition of the body, soul and social, allowing a person to live productively, socially, and economically (X2).

- Worker's performance is the result or level of an optimal person in carrying out the task or work (Y).

Table 3. Research Variables Indicators

\begin{tabular}{|c|c|c|c|}
\hline No & $\begin{array}{l}\text { Work Safety } \\
\text { (X1) }\end{array}$ & $\begin{array}{c}\text { Occupational } \\
\text { Health (X2) }\end{array}$ & $\begin{array}{c}\text { Worker } \\
\text { Performance (Y) }\end{array}$ \\
\hline 1 & $\begin{array}{c}\text { Work protective } \\
\text { equipment }\end{array}$ & $\begin{array}{c}\text { Medical } \\
\text { examination }\end{array}$ & Ability \\
\hline 2 & $\begin{array}{c}\text { A safe } \\
\text { workplace }\end{array}$ & Noise & $\begin{array}{l}\text { Effectiveness } \\
\text { and efficiency }\end{array}$ \\
\hline 3 & $\begin{array}{l}\text { Use of work } \\
\text { equipment }\end{array}$ & Time off & Attitude \\
\hline 4 & $\begin{array}{l}\text { Working } \\
\text { equipment } \\
\text { condition }\end{array}$ & $\begin{array}{l}\text { Enough lighting } \\
\text { when overtime }\end{array}$ & Situation \\
\hline 5 & $\begin{array}{l}\text { Work equipment } \\
\text { placement }\end{array}$ & $\begin{array}{c}\text { Workplace } \\
\text { Cleanliness }\end{array}$ & Skills \\
\hline
\end{tabular}

\section{Results and Discussion}

\subsection{Validity Test}

The validity test was conducted to statement items related to all indicators after surveying by distributing questionnaires to 50 respondents in the construction project of the shaft road and entry monument of the integrated district government office in Sumenep City District, Sumenep Regency. Then, the data containing the score of the statement items in the questionnaire were included in the table. Furthermore, the correlation value of each item to the total score was calculated. The results of the validity test, as shown in Table 4.

Table 4. Test Validity of Research Indicators

\begin{tabular}{|c|c|c|c|c|}
\hline No & Indicator & $\begin{array}{c}\text { The correlation } \\
\text { coefficient }(r \text {-count })\end{array}$ & $\begin{array}{c}\text { r-table value } \\
(\alpha=1 \%)\end{array}$ & Result \\
\hline 1 & X1.1 & 0.822 & 0.463 & Valid \\
\hline 2 & X1.2 & 0.709 & 0.463 & Valid \\
\hline 3 & X1.3 & 0.800 & 0.463 & Valid \\
\hline 4 & X1.4 & 0.752 & 0.463 & Valid \\
\hline 5 & X1.5 & 0.731 & 0.463 & Valid \\
\hline 6 & X1.6 & 0.614 & 0.463 & Valid \\
\hline 7 & X2.1 & 0.642 & 0.463 & Valid \\
\hline 8 & X2.2 & 0.701 & 0.463 & Valid \\
\hline 9 & X2.3 & 0.725 & 0.463 & Valid \\
\hline 10 & X2.4 & 0.774 & 0.463 & Valid \\
\hline 11 & X2.5 & 0.683 & 0.463 & Valid \\
\hline 12 & X2.6 & 0.641 & 0.463 & Valid \\
\hline 13 & X2.7 & 0.698 & 0.463 & Valid \\
\hline 14 & Y.1 & 0.785 & 0.463 & Valid \\
\hline 15 & Y.2 & 0.828 & 0.463 & Valid \\
\hline 16 & Y.3 & 0.861 & 0.463 & Valid \\
\hline 17 & Y.4 & 0.790 & 0.463 & Valid \\
\hline 18 & Y.5 & 0.752 & 0.463 & Valid \\
\hline 19 & Y.6 & 0.748 & 0.463 & Valid \\
\hline
\end{tabular}

\subsection{Reliability Test}

The reliability test technique used the alpha reliability coefficient. The decision-making criterion was that if the value of the alpha reliability coefficient is greater than 0.6 , the variable is reliable. The test results are shown in Table 5.

Table 5. Reliability Test Research Indicators

\begin{tabular}{|c|c|c|c|}
\hline No & Variable & $\begin{array}{c}\text { Alpha Reliability } \\
\text { Coefficient }\end{array}$ & Result \\
\hline 1 & Work Safety (X1) & 0.832 & Reliable \\
\hline 2 & $\begin{array}{c}\text { Occupational } \\
\text { Health (X2) }\end{array}$ & 0.819 & Reliable \\
\hline 3 & $\begin{array}{c}\text { Worker } \\
\text { Performance (Y) }\end{array}$ & 0.881 & Reliable \\
\hline
\end{tabular}

\subsection{Descriptive Analysis}

Descriptive analysis is conducted to find out about the implementation of occupational health and safety affecting the performance of workers, a percentage analysis was performed to calculate the percentage of the average score of each statement variable's item to describe the level of meeting a predetermined criterion. The results of the analysis are shown in Table 6.

Table 6. Descriptive Analysis Results

\begin{tabular}{|c|c|c|c|c|}
\hline No & Indicator & Total & Mean & Percentage \\
\hline 1 & $\mathrm{X} 1.1$ & 112 & 3.73 & $74 \%$ \\
\hline 2 & $\mathrm{X} 1.2$ & 119 & 3.97 & $79 \%$ \\
\hline 3 & $\mathrm{X} 1.3$ & 110 & 3.67 & $73 \%$ \\
\hline 4 & $\mathrm{X} 1.4$ & 122 & 4.07 & $81 \%$ \\
\hline 5 & $\mathrm{X} 1.5$ & 115 & 3.83 & $76 \%$ \\
\hline 6 & $\mathrm{X} 1.6$ & 112 & 3.73 & $74 \%$ \\
\hline 7 & $\mathrm{X} 2.1$ & 124 & 4.13 & $82 \%$ \\
\hline 8 & $\mathrm{X} 2.2$ & 114 & 3.80 & $76 \%$ \\
\hline 9 & $\mathrm{X} 2.3$ & 115 & 3.83 & $77 \%$ \\
\hline 10 & $\mathrm{X} 2.4$ & 111 & 3.70 & $74 \%$ \\
\hline 11 & $\mathrm{X} 2.5$ & 112 & 3.73 & $75 \%$ \\
\hline 12 & $\mathrm{X} 2.6$ & 110 & 3.67 & $73 \%$ \\
\hline 13 & $\mathrm{X} 2.7$ & 122 & 4.07 & $81 \%$ \\
\hline 14 & $\mathrm{Y} .1$ & 127 & 4.37 & $84 \%$ \\
\hline 15 & $\mathrm{Y} .2$ & 130 & 4.33 & $86 \%$ \\
\hline 16 & $\mathrm{Y} .3$ & 133 & 4.43 & $88 \%$ \\
\hline 17 & $\mathrm{Y} .4$ & 121 & 4.03 & $80 \%$ \\
\hline 18 & $\mathrm{Y} .5$ & 120 & 4.00 & $80 \%$ \\
\hline 19 & $\mathrm{Y} .6$ & 119 & 3.97 & $79 \%$ \\
\hline
\end{tabular}

The indicator with the highest Mean on the Work Safety (X1) is a statement that workers have properly used work equipment while doing work. The lowest mean value was that the company always controls the work location regularly. 
The indicator with the highest Mean in the Occupational Health (X2) is the statement that the company has provided first aid kits, while the lowest mean value is that workers feel comfortable when doing overtime work with adequate lighting at the project site.

The indicator with the highest Mean on Worker Performance (Y) is a statement that workers always maintain their attitudes and conform to the rules that have been set so that work targets are achieved. At the same time, the lowest mean value is the company provides workload based on the workers' skills.

\subsection{Multiple Linear Regression}

Linear regression analysis of research variables is a statistical calculation approach done by tabulating and calculating research data so that it produces output to conclude. The properties of the data can determine the calculation of the value of central tendency (a measure of primary value), for example, the mean and median values. The path diagram of the modelling results is shown in Figure 2. Based on the results of the F-Test and T-Test, the regression analysis results are obtained and shown in Table 7.

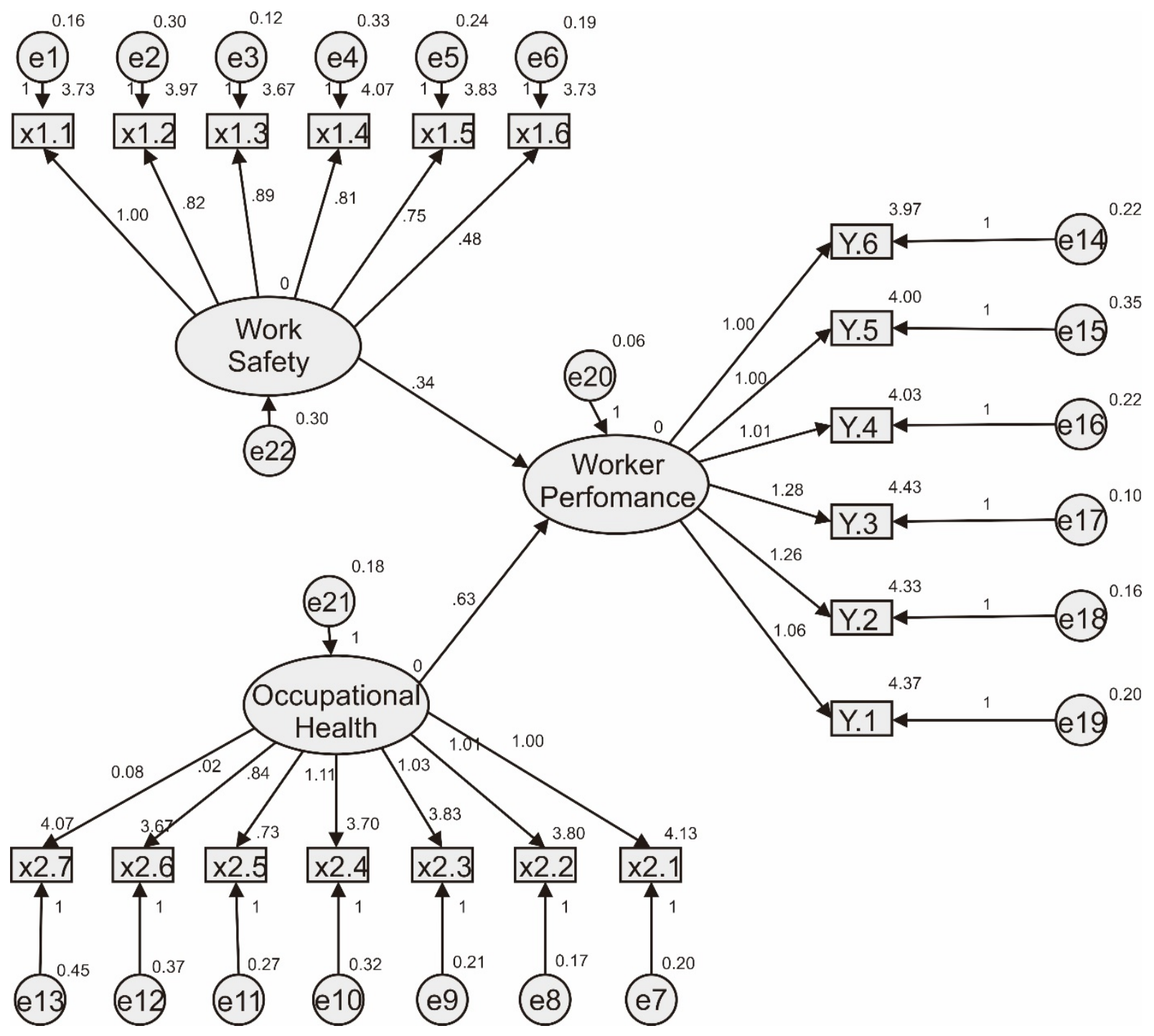

Figure 2. Path Diagram Analysis Result 
Table 7. Multiple Linear Regression Analysis Results

\begin{tabular}{|c|c|c|c|}
\hline Variable & $\mathrm{B}$ & $t_{\text {count }}$ & Sig. \\
\hline Work safety (X1) & 0.496 & 2.849 & 0.008 \\
Occupational health (X2) & 0.408 & 2.696 & 0.012 \\
Worker performance (Y) & & & \\
\hline
\end{tabular}

The details are as follows:

Constanta $: 2.743$

$\mathrm{R}: 0.743$

R. Square : 0.552

F-count : : 16.601

F-table $: 3.910$

Sig F : 0.000

T-table : 0.701

Multiple Linear Regression Equations

$$
Y=2.743+0,496 X_{1}+0,408 X_{2} \text {. }
$$

The result of the regression equation has the following meanings:

A constant of 2.743 shows results that affect Worker Performance (Y) of external variables are not included in this study, respondents' perceptions before the effect of occupational health and safety.

The regression coefficient on the work safety variable (X1) of 0.496 indicates that the implementation of work safety programs can affect improving worker performance (Y), which has positive coefficient values. Thus, it can be interpreted that the work safety programs appropriately implemented can be used as a driving force to increase employee performance $(\mathrm{Y})$ on other variables constant.

The regression coefficient on the occupational health variable (X2) of 0.408 shows that the company's efforts to maintain occupational health through health programs for workers and work environment health have an impact on improving employee performance (Y), which have the coefficient values not negative. This means that occupational health programs (X2) can improve worker performance $(\mathrm{Y})$ with constant variables. Thus, all research hypotheses can be accepted.

\subsection{Discussion}

However, this research finding support Busyairi's study [16], who researched the implementation of OHS in manufacturing companies, shows the same results that OHS has a positive effect on improving employee performance. Nonetheless, these results, contrary to Firmanzah's research [17] in the state electricity company showed that work safety variables had a negative and significant effect on employee performance. According to the respondent's answer, the performance of workers affected by the implementation of Occupational Health and Safety (OHS) has a positive effect on work because the work is in an open location and a lot of manual work is conducted by workers who need protection. For example, the safety helmets are worn on the head to protect the worker from the scorching heat of the sun and to focus more on open work; if workers do not wear safety helmets, the workers are troubled by the heat of the sun on free labour. Rubber boots are dressed in a mixing-work and manual excavating so that the workers are protected from foot injuries. According to the respondent, at around 25\% of the mixing-work progress, workers are injured when using shoes.

\section{Conclusions}

To conclude, the implementation of Occupational Health and Safety (OHS) factors affecting the performance of workers are as follows:

1. Work Safety Factor (X1) with the highest result of $\mathrm{X} 1.4=4.07$, with a percentage of $81 \%$ (Very Good); Occupational Health factor (X2) with the highest result of X2.1 $=4.13$, with a percentage of $82 \%$ (Very Good); Worker Performance factor (Y) with the highest result of Y.3 $=4.43$, with a percentage of $88 \%$ (Very Good).

2. From the results of interview responses, the Occupational Health and Safety (OHS) has a positive effect on the performance of workers since this job is in an open location and involves a lot of manual works.

The contributions of this research are:

1. Theoretically, it would increase knowledge in the field of OHS regarding the effect of the implementation of occupational safety and health (OHS) programs and work motivation on worker productivity. This study is used as further research material for other researchers interested in this field, and supports previous research that there is an effect of the implementation of occupational safety and health (OHS) programs and work motivation on worker productivity.

2. Practically, for companies engaged in fields other than construction services, they can find out the extent of the programs that have been carried out in construction projects and know the importance of the implementation of the Occupational Safety and Health (OHS) program to support the improvement of worker performance.

Accordingly, the following limitations and future directions for the next research are:

- Because the main limitation of this study is the small sample size, further research expects to collect more samples of respondents from several types and project locations.

- The application of different analytical methods or research variables would increase the performance of workers. It is also expected that further research will be expanded that there will be more broad conclusions and benefits of study on occupational 
safety and health, given the occupational risks in a company.

- $\quad$ Project implementers expect to carry out Occupational Health and Safety (OHS) conforming to applicable regulations and to complete the required personal protective equipment (PPE) to improve the performance of construction workers further.

\section{Acknowledgements}

We are very grateful to the construction company for their appropriate and constructive suggestions to support the data of this study.

\section{REFERENCES}

[1] Handoko, F., Vitasari, P., Hidayat, S., Tjahjadi, M E., Technology Transfer Program for SME's in Indonesia. Journal of Physics: Conference Series, Vol. 1375, 2019. Doi:10.1088/1742-6596/1375/1/012053

[2] Handoko, F. "Constructing Knowledge and Technology Transfer Model for SMEs Technology Development in Emerging Economies". International Journal of Pedagogy and Teacher Education. Vol 1, No. 2. pp. 93, 2017

[3] Handoko, F, Alan, S, and Burvill, C., The Role of Government, Universities, and Business in Advancing Technology for SMEs' innovation. Journal of Chinese Economic and Business Studies. Vol 12, No. 2. pp. 171, 2014.

[4] Handoko, F., Nursanti, E., Harmanto, D and Sutriyono. The role of tacit and codified knowledge within technology transfer program on technology adaptation. ARPN Journal of Engineering and Applied Sciences, Vol.11, No. 8, 2016.

[5] Hidayat, S., Handoko, F., Tjahjadi, M E., Vitasari, P. The Triple Helix and Technology Capability and Competitiveness of SMEs in Developing Economy. International Journal of Civil Engineering and Technology, 9(13), pp. 366-378, 2018.

[6] Handoko, F., Nursanti, E., Gatot, Tjahjadi, M.E., Hutabarat, J., Mulyadi, L., and Kustamar. Green Industrial System in Indonesia". MATEC Web Conf., 164 (2018) 01010, DOI: https://doi.org/10.1051/matecconf/201816401010

[7] Wijayaningtyas, M., Handoko, F., Hidayat, S., The Millennials' Perceived Behavioural Control on an Eco-friendly House Purchase Intention. Journal of Physics: Conference Series, Vol. 1375, 2019. Doi:10.1088/1742-6596/1375/1/012060

[8] Saputra, P.D. and Latief, Y. Development of Safety Plan Based on Work Breakdown Structure to Determine Safety Cost Precast Concrete Bridge Construction Projects. Case Study: Girder Erection with Launching Gantry Method. Civil Engineering and Architecture, 8, 3, 297-302, 2020.

[9] Kamaruddeen, A.M., Sung, C.F., and Wahi, W. A Study on Factors Causing Cost Overrun of Construction Projects in
Sarawak, Malaysia. Civil Engineering and Architecture, 8, 3, 191-199, 2020.

[10] Wijayaningtyas, Maranatha; Sipan, Ibrahim; Lukiyanto, Kukuh. Informal worker phenomenon in a housing construction project, AIP Conference Proceedings, 1903,1,070006,2017, AIP Publishing LLC, 2017.

[11] Kustamar, Maranatha Wijayaningtyas, Muhamad Irfan. Value Engineering Application in Avtur Pipeline Work at Juanda International Airport, International Journal of Scientific and Technology Research, 8, 10, 1092-1096, 2019.

[12] Wijayaningtyas, M., Seran, S., Mulyadi, L., Iskandar, T.,' Pengaruh Faktor Eksternal dan Internal terhadap Produktivitas Tenaga Kerja Proyek Pembangunan Gedung," (The impact of external and internal factor on high building worker productivity) Prosiding Semsina, V1-V6, 2019.

[13] Mangkunegara, A. P., "Manajemen Sumber Daya Manusia Perusahaan," (Managing Company's Human Resource Development), 2nd ed. Bandung: PT. Remaja Rosda Karya, pp. 15-64, 2000.

[14] Hanggraeni, D., "Manajemen Sumber Daya Manusia," (Managing Human Resource Development). Jakarta: FEUI, pp. 123-135, 2012.

[15] Ramli, S., "Sistem Manajemen Keselamaran dan Kesehatan Kerja OHSAS 18001" (Occupational Health and Safety Management System OHSAS 18001). Jakarta: PT. Dian Rakyat, pp. 24-30. 2010.

[16] Busyairi, M., La Ode, A.S.T. \& Ayu O. (2014). Pengaruh Keselamatan Kerja Dan Kesehatan Kerja Terhadap Produktivitas Kerja Karyawan (The Effect of Occupational Safety and Health on Employee Work Productivity). Jurnal Ilmiah Teknik Industri, Vol. 13, No. 2, Des 2014 ISSN 1412-6869.

[17] Firmanzah, A., Djamhur H. \& Djudi, M. "Pengaruh Keselamatan Dan Kesehatan Kerja Terhadap Kinerja Karyawan (Studi Pada Karyawan PT. PLN (Persero) Area Kediri Distribusi Jawa Timur)," (The Impact of Occupational Health and Safety on Employee's Performance (Case study on PT. PLN (Persero) Kediri district, East Java Distribution) Jurnal Administrasi Bisnis, vol. 42 (2), pp. 45-50, Jan. 2017.

[18] Swasto, B., "Manajemen Personalia" (Managing People). Yogyakarta: BPFE, pp. 55-70, 2011.

[19] Suprihatno, J., "Perilaku Organisasional" (Organisation Behaviour). Yogyakarta: STIE YKPN, pp. 45-60, 2003.

[20] Manulang, "Manajemen Personalia" (Managing People). Yogyakarta: Gadjah Mada University Press, pp. 87-90, 2006.

[21] Simamora, H. "Manajemen Sumber Daya Manusia" (Managing Human Resource Development). Yogyakarta: STIE YKPN, pp. 55-60, 2004.

[22] Mangkunegara, A. P. (2000). "Manajemen Sumber Daya Manusia Perusahaan" (Corporate Human Resource Management). Bandung: Cetakan Ke-2, PT. Remaja Rosda Karya.

[23] Dewi, R. (2006). *Pengaruh Keselamatan Dan Kesehatan 
Kerja Terhadap Kinerja Karyawan Pada PT. Ecogreen Oleochemicals Medan Plant* (The Effect of Occupational Safety and Health on Employee Performance at PT. Ecogreen Oleochemicals Medan Plant). Undergraduate Essay. Medan: Economy Faculty, Sumatera Utara University.

[24] Indriasari, N. (2008). "Pengaruh keselamatan dan kesehatan kerja (K3) terdapat kinerja karyawan (Studi pada PT Surabaya agung industry pulp \& kertas)" (The effect of occupational safety and health (K3) is employee performance (Study at PT Surabaya agung pulp \& paper industry). Undergraduate Essay. Malang: Faculty of
Administrative Sciences, Brawijaya University.

[25] Sulisyarini, Wahyu Ratna (2006). "Pengaruh Program Keselamatan Dan Kesehatan Kerja (K3) Terhadap Produktivitas Kerja Karyawan (Studi Pada CV. Sahabat Di Klaten)" (The Effect of Occupational Safety and Health (K3) Program on Employee Productivity (Study in CV. Friends in Klaten). Undergraduate Essay. Surakarta: Faculty of Economy, State Islamic High School.

[26] Sugiyono, "Metode Penelitian Kuantitatif, Kualitatif dan R\&D" Research Method on Quantitative, Qualitative and R\&D). Bandung: Alfabeta, pp. 30-130, 2010. 

